\title{
Pathogenesis of Leptospirosis: Important Issues
}

\author{
Márcia Marinho* and Tereza Cristina Cardoso \\ Support Department, Animal Production and Health Microbiology Laboratory, State University of Sao Paulo, Brazil
}

\begin{abstract}
The leptospirosis is a re-emerging anthropozoonos is worldwide distribution. The immunopathogenesis of the disease is extremely complex. Which one the role of inflammatory mediatorys, cytokines, outer membrane proteins, apoptosis and others factors related with the virulence of the pathogen during the infection.
\end{abstract}

\section{Summary}

Leptospirosis is a re-emerging tropical infectious disease [1], is an important zooanthroponotic disease spread-worldwide [2]. The spirochetes of the genus Leptospira is responsible of human and animal leptospirosis characterized as mild febrile illness to severe multiorgan failure, especially pulmonary hemorrhage and renal failure [3]. Pathogenic leptospires are highly motile and invasive spirochetes that have the capacity to survive and grow in tissue by escaping natural defense mechanism [4]. The disease is transmitted to humans by direct or indirect exposure to contaminated urine from mammalian reservoir hosts as rodents but also farm, wild, and domestic mammals [5]. Asymptomatic form of leptospirosis with fever, headache, and myalgia that can spontaneously resolve is one of clinical presentations [3]. The most cases are probably inapparent and associated with host-adapted serovars such as Canicola in dogs, Bratislava in horses and pigs, Hardjo in cattle and Australis and Pomona in pigs [6-9].

In humans can vary in severity according to the infection serovar of Leptospira, and the age, health and immunological competence of the patient [2]. However, more severe cases, with sepsis and multiple organ failure, including hepatic and renal dysfunctions associated to pulmonary hemorrhage, are also reported [3]. Leptospires enter the body through small cuts or abrasions, via mucous membranes such as the conjunctiva or thorough wet skin. They circulate in the blood stream, with the bacteremic phase lasting for up to 7 days [2]. The second stage of acute leptospirosis is also referred to as the immune phase, in with the disappearance of the organism from the bloodstream coincides with the appearance of antibodies [5]. The mechanisms by which leptospires cause disease are not well understood. The presence of the virulence factors has been suggested. The involvement of toxins or toxic factors in the pathogenesis of leptospirosis has long been contemplated, since the absence of the microorganism at the site of tissue injury is a factor that strengthens this hypothesis $[10,11]$ extracted a glycoprotein (GLP) present in cell walls of a strain of serovar L.interrogans Copenhageni that cytotoxic effect against the fibroblasts of mice (L929). Later it was demonstrated that GLP induced the production of cytokines, TNF- $\alpha$ and IL-10 by peripheral blood monocytes of healthy volunteers [12]. The mechanism by which leptospira activate the immune system has been the main focus of many studies, especially regarding the involvement of cytokines [13,14]. High levels of TNF- $\alpha$ in serum of patients with leptospirosis were observed and in the culture supernatant of macrophages [15-18], and also associated the severity of infection. Tests using the technique of quantitative real-time PCR, found elevated levels of inflammatory cytokines, IL- 4 and IL-10 in the late stage of infection with Leptospira interrogans Icterohaemorrhagiae establishing a profile of involvement of cytokines in type 1 cellular immunity $[19,20]$. It is believed that the naturally acquired immunity may result from humoral-mediated response [21,22] which in turn serovarspecific [21]. The development of the humoral response is related to activation-dependent mechanism recetor Tool-like type 2 (TLR-2), via the innate immune system that would be activated by LPS leptospiral [23]. Other researchers [24], demonstrated that Leptospira can activate $\mathrm{T}$ cell proliferation and $\gamma-\delta \alpha-\beta$, suggesting therefore the involvement of these cell populations in host defense or in the pathology of leptospirosis. But the adhesion of leptospires to host tissue components is important as an initial and necessary step for infection and pathogenesis. Therefore, much recent leptopirosis research has focused on outer membrane proteins (OMPs) such as LipL32 [25], the bacterial immunoglobulin-like domain containing proteins (LigA-C) [26,27] the leptospiral endostatin-like proteins (LenA-F) [28]. Several studies recently showed that recombinant Lig proteins can mediate in vitro interaction with fibronectin, fibrinogen, collagen, laminin, tropoelastin, and elastin [29,30]. Others virulence factor might be of greater significance in the pathogenesis of leptospirosis would be the occurrence of apoptosis cellular or programmed cell death that is an essential mechanism for embryonic development and host response against many infectious and non-infectious disease [31] followed by tissues injury is well documented, including many renal diseases [32] $L$. interrogans serovar Icterohaemorrhagiae infection has been described to invade Vero cells and induce macrophages apoptosis [33]. Besides, in vivo apoptosis of hepatocytes of guinea pig infected by the same serovar has been described [34]. It has been demonstrated that L. interrogans induces apoptosis in J774A1 cells by activation of caspases- 3 through activation of caspase-8 [35]. The clinical severity of the disease often appears to be out of proportion to the histopathological findings. Immune-mediated disease has been proposed as one factor influencing the severity of the symptoms [5]. The presence of the IgM, IgG and IgA and $\mathrm{C} 3$ along the alveolar basement membrane, were demonstrated, suggesting that as autoimmune process constitutes the etiology of fatal hemorrhagic complications due to leptospirosis [36]. A strong immunostaining of both Il-6 and TNF- $\alpha$ was observed in addition to glomerular hypercellularity in Balb/c mice inoculated with Leptopira interrogans serovar Canicola [37]. Finally studies show that the expression of genes responsible for virulence factors in leptospira is pathogen-specific genes and that may be expressed or not depending

*Corresponding author: Márcia Marinho, Support Department, Animal Production and Health Microbiology Laboratory, State University of Sao Paulo, Brazil, Tel: 18-3636-1382; E-mail: mmarinho@fmva.unesp.br

Received January 27, 2015; Accepted January 27, 2015; Published January 29 2015

Citation: Marinho M, Cardoso TC (2015) Pathogenesis of Leptospirosis: Important Issues. J Med Microb Diagn 4: e127. doi:10.4172/21610703.1000e127

Copyright: ( 2015 Marinho M, et al. This is an open-access article distributed under the terms of the Creative Commons Attribution License, which permits unrestricted use, distribution, and reproduction in any medium, provided the original author and source are credited. 
on the pathogen's ability to attach to host tissues during infection. However, additional research is essential to understanding how, the mechanisms by which leptospira induces the tissue injury and what role that virulent factors on the pathophysiology of leptospirosis.

\section{References}

1. Xue F, Zhao X, Yang Y, Zhao J, Yang Y et al. (2013) Responses of murine and human macrophages to Leptospiral Infection. A study using comparative array analysis. PLOS Negl Trop Dis 7: 2410-2477

2. Adler B, de la Peña Moctezuma A (2010) Leptospira and leptospirosis. Vet Microbiol 140: 287-296.

3. Bharti AR, Nally JE, Ricaldi JN, Matthias MA, Diaz MM, et al. (2003) Leptospirosis: a zoonotic disease of global importance. Lancet Infect Dis 3: 757-771.

4. Mcbried AJA, Athanazio DA, Reis MG, Ko Al (2005) Leptospirosis. Curr Opin Infect Dis 18: 595-603.

5. Levett PN (2001) Leptospirosis. Clin Microbiol Rev 14: 296-326.

6. André-Fontaine G (2006) Canine leptospirosis--do we have a problem? Vet Microbiol 117: 19-24.

7. Bernard WV (1993) Leptospirosis. Vet Clin North Am Equine Pract 9: 435-444.

8. Ellis WA, McParland PJ, Bryson DG, Thiermann AB, Montgomery J (1986) Isolation of leptospires from the genital tract and kidneys of aborted sows. Vet Rec 118: 294-295.

9. Grooms DL (2006) Reproductive losses caused by bovine viral diarrhea virus and leptospirosis. Theriogenology 66: 624-628.

10. Knight LL, Miller NG, White RJ (1973) Cytotoxic factor in the blood and plasma of animals during leptospirosis. Infect Immun 8: 401-405.

11. Vinh T, Adler B, Faine S (1986) Glycolipoprotein cytotoxin from Leptospira interrogans serovar copenhageni. J Gen Microbiol 132: 111-123.

12. Diament D, Brunialti MK, Romero EC, Kallas EG, Salomao R (2002) Peripheral blood mononuclear cell activation induced by Leptospira interrogans glycolipoprotein. Infect Immun 70: 1677-1683.

13. Yang CW, Wu MS, Pan MJ, Hong JJ, Yu CC, et al. (2000) Leptospira outer membrane protein activates NF-kappaB and downstream genes expressed in medullary thick ascending limb cells. J Am Soc Nephrol 11: 2017-2026.

14. Marangoni A, Aldini R, Sambri V, Giacani L, Di Leo K, et al. (2004) Production of tumor necrosis factor alpha by Treponema pallidum, Borrelia burgdorferi s.l., and Leptospira interrogans in isolated rat Kupffer cells. FEMS Immunol Med Microbiol 40: 187-191.

15. Estavoyer JM, Racadot E, Couetdic G, Leroy J, Grosperrin L (1991) Tumo necrosis factor in patients with leptospirosis. Rev Infect Dis 13: 1245-1246.

16. Tajiki H, Salomão R (1996) Association of plasma levels of tumor necrosis factor alpha with severity of disease and mortality among patients with leptospirosis. Clin Infect Dis 23: 1177-1178.

17. Marinho M, Langoni H, Oliveira SL, Lima VMF, Peiró JR, Perri SHV, et al. (2005) Role of cytokines, $\mathrm{NO}$, and $\mathrm{H} 2 \mathrm{O} 2$ on the immunopathology of Leptospirosis in genetically selected mice. J Venom Anim Tox incl Trop 11: 198-212

18. Marinho M, Silva C, Lima VMF, Peiró JR, Perri SHV (2006) Cytokine and antibody production during murine leptospirosis. J Venom Anim Toxins incl Trop Dis 12: 595-603.

19. Vernel-Pauillac F, Merien F (2006) Proinflammatory and immunomodulatory cytokine mRNA time course profiles in hamsters infected with a virulent variant of Leptospira interrogans. Infect Immun 74: 4172-4179.
20. Marinho M, Oliveira-Júnior IS, Monteiro CM, Perri SH, Salomão R (2009) Pulmonary disease in hamsters infected with Leptospira interrogans: histopathologic findings and cytokine mRNA expressions. Am J Trop Med Hyg 80: 832-836.

21. Adler B, Faine S (1977) Host immunological mechanisms in the resistance of mice to leptospiral infections. Infect Immun 17: 67-72.

22. Adler B, Murphy AM, Locarnini SA, Faine S (1980) Detection of specific antileptospiral immunoglobulins $\mathrm{M}$ and $\mathrm{G}$ in human serum by solid-phase enzymelinked immunosorbent assay. J Clin Microbiol 11: 452-457.

23. Werts C, Tapping RI, Mathison JC, Chuang TH, Kravchenko V, et al. (2001) Leptospiral lipopolysaccharide activates cells through a TLR2-dependent mechanism. Nat Immunol 2: 346-352.

24. Klimpel GR, Matthias MA, Vinetz JM (2003) Leptospira interrogans activation of human peripheral blood mononuclear cells: preferential expansion of TCR gamma delta+ T cells vs TCR alpha beta+ T cells. J Immunol 171: 1447-1455

25. Murray GL (2013) The lipoprotein LipL32, an enigma of leptospiral biology. Vet Microbiol 162: 305-314

26. Lin YP, McDonough SP, Sharma Y, Chang YF (2010) The terminal immunoglobulin-like repeats of LigA and LigB of Leptospira enhance their binding to gelatin binding domain of fibronectin and host cells. PLoS One 5 e11301.

27. Choy HA, Kelley MM, Croda J, Matsunaga J, Babbitt JT, et al. (2011) The multifunctional LigB adhesin binds homeostatic proteins with potential roles in cutaneous infection by pathogenic Leptospira interrogans. PLoS One 6 : e16879.

28. Stevenson B, Choy HA, Pinne M, Rotondi ML, Miller MC, et al. (2007) Leptospira interrogans endostatin-like outer membrane proteins bind host fibronectin, laminin and regulators of complement. PLoS One 2: e1188.

29. Choy HA, Kelley MM, Chen TL, Møller AK, Matsunaga J, et al. (2007) Physiological osmotic induction of Leptospira interrogans adhesion: LigA and LigB bind extracellular matrix proteins and fibrinogen. Infect Immun 75: 2441-2450.

30. Lin YP, Greenwood A, Yan W, Nicholson LK, Sharma Y, et al. (2009) A nove fibronectin type III module binding motif identified on C-terminus of Leptospira immunoglobulin-like protein, LigB. Biochem Biophys Res Commun 389: 57-62.

31. Boatright KM, Salvesen GS (2003) Mechanisms of caspase activation. Curr Opin Cell Biol 15: 725-731.

32. Jo SK, Yun SY, Chang KH, Cha DR, Cho WY, et al. (2001) alpha-MSH decreases apoptosis in ischaemic acute renal failure in rats: possible mechanism of this beneficial effect. Nephrol Dial Transplant 16: 1583-1591.

33. Merien F, Baranton G, Perolat P (1997) Invasion of Vero cells and induction of apoptosis in macrophages by pathogenic Leptospira interrogans are correlated with virulence. Infect Immun 65: 729-738.

34. Merien F, Truccolo J, Rougier Y, Baranton G, Perolat $P$ (1998) In vivo apoptosis of hepatocytes in guinea pigs infected with Leptospira interrogans serovar icterohaemorrhagiae. FEMS Microbiol Lett 169: 95-102.

35. Li SJ, Hu Y, Yan J, Mao YF, Li LW (2008) [Upregulation of FasL/Fas expression and FasL/Fas-associated apoptosis in J774A.1 cells induced by Leptospira interrogans]. Zhejiang Da Xue Xue Bao Yi Xue Ban 37: 551-557.

36. Nally JE, Chantranuwat C, Wu XY, Fishbein MC, Pereira MM, et al. (2004) Alveolar septal deposition of immunoglobulin and complement parallels pulmonary hemorrhage in a guinea pig model of severe pulmonary leptospirosis. Am J Pathol 164: 1115-1127.

37. Marinho M, Monteiro CMR, Peiró JR, Machado GF, Oliveira Júnior IS (2008) TNF-a and IL-6 immunohistochemistry in rat renal tissue experimentally infected with Leptospira interrogans serovar Canicola. J Venom Anim Tox inc Trop Dis 14: $533-40$ 